\title{
CHARACTERIZATION OF CEMENT KILN DUST STABILIZED BLACK COTTON SOIL
}

\author{
Prathap Kumar ${ }^{1}$, Sapna Devendra ${ }^{2}$ \\ ${ }^{1}$ Professor \& Head of the Department-CIVIL, RNS Institute of Technology, Bengaluru-560098 \\ ${ }^{2}$ Research Scholar, GCE, Ramanagara \& Regional Manager, Alccofine Product, Ambuja Cement Ltd. Bengaluru- \\ 560085
}

\begin{abstract}
Cement kiln dust (CKD), being a waste product from cement industry is explored in the present study as a stabilizing material for black cotton soil(BC soil). In the present study, characterization of BC soil for Atterberg's limits, Specific gravity, $p H$, compaction characteristics and unconfined compressive strength were conducted by admixing with CKD at different percentage. The results of the present study indicates that, both liquid limit and plastic limit increases with increase in CKD percentage. It was found that UCS increases with increase in curing period for BC soil admixed with 12\%CKD. It was concluded that 12\% CKD produce optimum benefits in terms of reduction in plasticity and increase in strength of BC soil admixed with CKD. CKD being an industrial waste thus can be used to stabilize BC soils to improve its engineering performance as a stabilized material.
\end{abstract}

Keywords: Cement Kiln Dust, Black Cotton Soil, Unconfined Compressive strength, Plasticity, Maximum Dry Density, Swelling, Stabilization.

\section{INTRODUCTION}

Black cotton soils (BC soils) are inorganic clays of medium to high compressibility and form a major soil group in India. These clays predominantly montmorillonite in structure and colour being blackish grey or black. BC soil has posed a challenge to highway and geo-technical engineers because of high shrinkage and swelling characteristics. The soil gets hard when it's dry but loses its strength completely in wet condition. Due to this wetting and drying processes, a vertical movement in soil mass occurs which leads to pavement failure in the form of cracking, settlement, unevenness and depression. These expansive soils are frequently used for construction purpose as it is easily available at low cost. Factors which influence the behavior of expansive soils are initial dry density, initial moisture content, Atterberg's limits of soil, amount and type of clay and swell potential. In order to improve the black cotton soil properties, it is always imperative to explore use of industrial wastes for sustainability and reduce environmental pollution. Cement kiln dust(CKD), being a waste product from cement industry is explored in the present study as a stabilizing material

Cement kiln dust is a finely divided, solid, high alkaline substance that is removed from cement kiln exhaust gas by scrubbers (electrostatic precipitators and /or filtration bag houses). CKD contains a combination of raw feed and calcined constituents with some volatile salts. CKD fraction differs from Portland cement as it is not been fully burnt, it differs chemically from the former. Due to high alkali content of CKD, its disposal as well as recycling poses problems. Cement kiln dust (CKD) seem to be suitable as a stabilizer to improve strength and compaction properties of
BC soil. The Cement Kiln Dust (CKD) brought from the wastes at the ACC cement production plant which is located at Wadi of Gulbarga District is used in the present study. Since soil stabilization mechanism requires calcium (form of lime) as the main stabilizing agent, CKD is used which comprises high free lime (calcium oxide) for stabilization of Clay soil.

Several studies have been reported in literature regarding the use of cement kiln dust as stabilizer. Southgate and Mahboub (1994)reported that the strength and modulus of elasticity of the stabilized soils positively correlates with the CBR test. Swelling potential can be reduce by adding CKD to the clayey soil. Results showed that swelling potential fell from $9 \%$ to $0.5 \%$ and raw clay swelling fell from $9 \%$ to $0 \%$ with the addition of $25 \% \mathrm{CKD}$ to the clayey soil.Heeralal and Praveen (2011)have examined the clayey soil by adding admixture like polypropylene fiber and cement kiln dust in 3 different percentages such as $0.25 \%, 0.5 \%, 1 \%$ by weight of the soil and $3 \%, 5 \%, 8 \%$ by weight of the soil respectively. Various tests were conducted such as CBR, Direct shear and Unconfined Compression Tests. The test results showed that there was an increase in the shear strength, Unconfined Compressive Strength (UCS), decrease the stiffness and for unsoaked condition also there was an increase in the CBR value. Oriola and G. Moses (2011)have replaced CKD upto $16 \%$ by dry weight of soil. Specimen were prepared for the water contents $+4 \%,+2 \%, 0 \%$ and $-2 \%$ of the optimum percentage of moisture content at the compactive energy levels of West African Standard (WAS). Unconfined Compression Test (UCT) and index properties tests were carried out. The result showed that black cotton soil treated with CKD was attained at $12 \%$ and $16 \%$ CKD content for specimen prepared of water content range of $16.7 \%$ to 
$21.6 \%$ and $17.2 \%$ to $19.3 \%$ respectively. The use of CKD as a stabilizer for black cotton soil have also been reported by other investigators. However, the effect of curing on the plasticity properties and strength are scarce in literature.

In the present study, characterization of BC soil for Atterberg's limits, Specific gravity, $\mathrm{pH}$, compaction characteristics and unconfined compressive strength were conducted by admixing with CKD at different percentage. $\mathrm{BC}$ soil passing $4.75 \mathrm{~mm}$ I.S. sieve and pulverized was used with CKD being added at different percentages of $0 \%, 4 \%$, $8 \%, 12 \% 16 \%$ and $20 \%$. The optimum percentage of CKD that gives maximum strength and reduces plasticity was arrived at based on the experimental study.

\section{MATERIALS AND METHODS}

The present investigations have been made using black cotton soil obtained The BC soil for the present study was obtained at a depth of $1 \mathrm{~m}$ below the ground level from Gangapura in Gulbarga district. The soil passing 425 micron sieve was used in the present study. Table 1 shows various index properties of $\mathrm{BC}$ soil used in the present study

Table 1 Index Properties of Black Cotton Soil

\begin{tabular}{|c|c|c|}
\hline $\begin{array}{l}\text { Index Properties of } \\
\text { Black Cotton Soil }\end{array}$ & $\begin{array}{l}\text { Obtained } \\
\text { values }\end{array}$ & $\begin{array}{l}\text { Relevant IS } \\
\text { Codes }\end{array}$ \\
\hline Liquid Limit \% & 65 & $\begin{array}{lll}\text { IS } 2720 \text { Part } \\
\text { V }\end{array}$ \\
\hline Plastic Limit \% & 26.9 & $\begin{array}{l}\text { IS } 2720 \text { Part } \\
\text { V }\end{array}$ \\
\hline Plasticity Index $\%$ & 38.1 & $\begin{array}{l}\text { IS } 2720 \text { Part } \\
\text { V }\end{array}$ \\
\hline$\%$ of Silt \& Clay & 85 & $\begin{array}{l}\text { IS } 2720 \text { Part } \\
\text { IV }\end{array}$ \\
\hline Specific Gravity & 2.65 & $\begin{array}{l}\text { IS } 2720 \text { Part } \\
\text { III }\end{array}$ \\
\hline $\begin{array}{l}\text { Max Dry density, } \\
\mathrm{kg} / \mathrm{m} 3\end{array}$ & 19.55 & $\begin{array}{l}\text { IS } 2720 \text { Part } \\
\text { VIII }\end{array}$ \\
\hline OMC \% & 30.51 & $\begin{array}{l}\text { IS } 2720 \text { Part } \\
\text { VIII }\end{array}$ \\
\hline $\begin{array}{l}\text { Unconfined } \\
\text { Compressive strength } \\
\text { at } \mathrm{OMC}, \mathrm{kN} / \mathrm{m} 2\end{array}$ & 155.19 & $\begin{array}{l}\text { IS } 2720 \text { Part } \\
\mathrm{X}\end{array}$ \\
\hline
\end{tabular}

The cement kiln dust (CKD) was obtained from freshly deposited heaps of the waste at the ACC cement production plant located in Wadi of Gulbarga district.

Once the physical properties of $\mathrm{BC}$ soil and $\mathrm{CKD}$ is evaluated, the determination of OMC and MDD for BC soil and $\mathrm{BC}$ soil admixed with trial percentages of CKD by weight of BC soil. The trial percentages adopted were $4 \%$, $8 \%, 12 \%, 16 \%$ and $20 \%$. Problems such as large quantities of soil, time duration and lot of effort are required to conduct standard compaction test. To overcome some of these problems, mini compaction apparatus suggested by Sridharan and Siva Pullaiah (2005) was used. Compaction characteristics were determined using the mini compaction apparatus by compacting soil in 3 layers with 45 blows for each layer. Determination of UCC of BC soil and BC soil admixed with trial percentages of CKD dry weight of $\mathrm{BC}$ soil. The samples were prepared for different curing periods of 7, 14 and 28 days. Analysis of compaction and UCC test results to arrive at optimum dosage of CKD to the $\mathrm{BC}$ soil. In the present study the unconfined compression test is conducted according to IS: 2720 (part 10) - 1991 (SP 16, 1997).

\section{RESULTS AND DISCUSSION}

\subsection{General}

Black Cotton soil was admixed with Cement Kiln Dust with its percentage being varied from $4 \%, 8 \%, 12 \%, 16 \%$ and $20 \%$ to determine the optimum percentage of CKD that causes a consequent reduction in plasticity. Tests such as liquid limit, plastic limit and variation of $\mathrm{pH}$ of $\mathrm{CKD}$ admixed BC soil were tested.

\subsection{Effect of CKD on Plasticity Characteristics and}

\section{pH}

Table: 3 shows variation of liquid limit, plastic limit and plasticity index as well as $\mathrm{pH}$ with increasing percentage of $\mathrm{CKD}$ in $\mathrm{BC}$ soil. Figure 1 shows variation of plasticity characteristics of $\mathrm{CKD}$ admixed $\mathrm{BC}$ soil. Figure 2 shows variation of $\mathrm{pH}$ for $\mathrm{BC}$ soil admixed with $\mathrm{CKD}$.

Table 3: Effect of CKD on Plasticity Characteristics and $\mathrm{pH}$

\begin{tabular}{|c|c|c|c|c|c|c|}
\hline \multirow{2}{*}{ Properties of Soil } & \multicolumn{7}{|c|}{ CKD\% } \\
\cline { 2 - 7 } & 0 & 4 & 8 & 12 & 16 & 20 \\
\hline LL\% & 65 & 71.2 & 72 & 73 & 71.8 & 70 \\
\hline PL\% & 26.95 & 31.2 & 32.66 & 37.43 & 32.28 & 31.62 \\
\hline PI\% & 38.05 & 40 & 39.34 & 35.27 & 39.52 & 38.38 \\
\hline PH & 7.35 & 7.68 & 7.72 & 7.55 & 7.42 & 7.4 \\
\hline
\end{tabular}

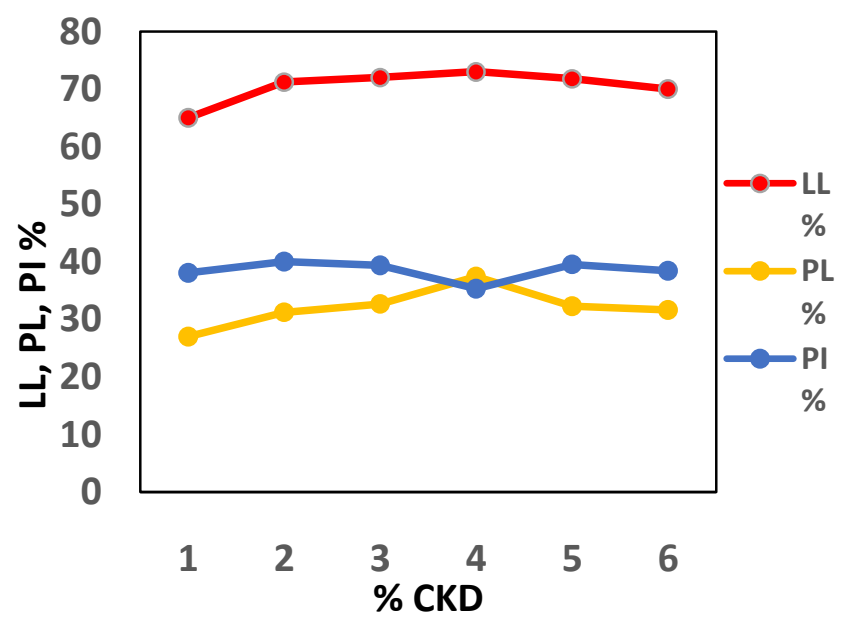

Fig 1 Variation of Plasticity Characteristics of CKD Admixed BC Soil 


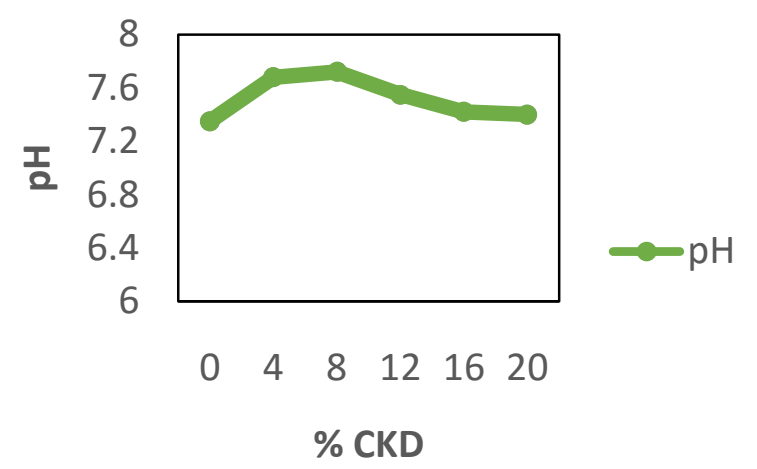

Fig 2 Variation of pH Curves for Black Cotton Soil Admixed with CKD

It can be seen that both liquid limit and plastic limit increases with increase in CKD percentage and seem to stabilize when percentage of CKD increases beyond $12 \%$ with a consequent reduction in plasticity index when percentage of CKD equals to $12 \%$. Also variation of $\mathrm{pH}$ indicates marginal increase of $\mathrm{pH}$ between $4 \%$ to $8 \%$ CKD. Thereafter the $\mathrm{pH}$ reduces and stabilizes beyond $12 \%$ CKD.

\subsection{Effect of $12 \%$ CKD on Compaction}

\section{Characteristics of Black Cotton Soil}

BC soil was admixed with $12 \%$ CKD and mini compaction test was done for $\mathrm{BC}$ soil alone and $\mathrm{BC}$ soil admixed with $12 \%$ CKD. Figure 3 shows compaction curves obtained for $\mathrm{BC}$ soil alone and $\mathrm{BC}$ soil $+12 \% \mathrm{CKD}$.

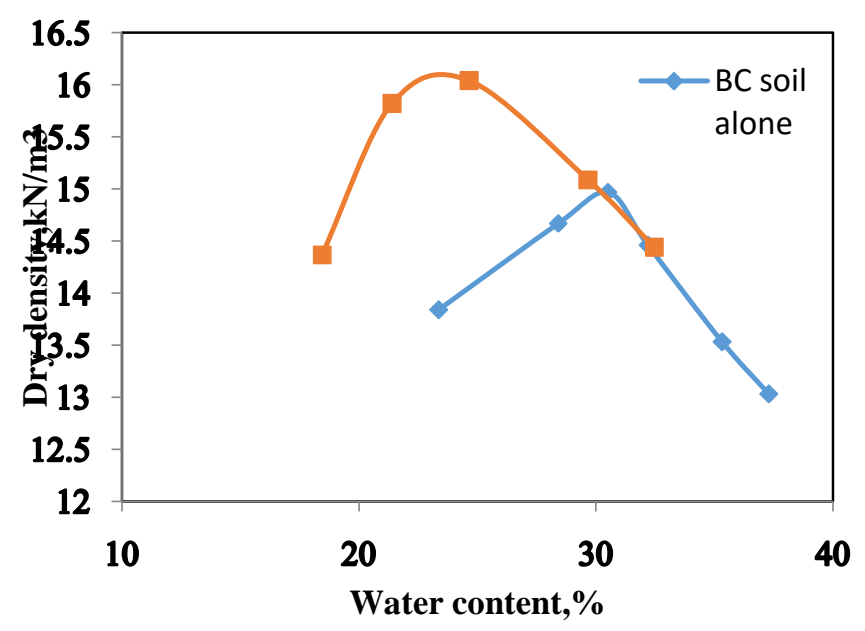

Fig 3 Compaction Curves Obtained for BC Soil Alone and BC Soil + 12\% CKD

BC soil $+12 \%$ CKD showed significant increase in maximum dry density with a corresponding reduction in OMC optimum moisture content which is desirable. Further to verify the effect of different percentage of CKD on strength of BC soil, unconfined Compression Test (UCT) was also conducted by admixing BC soil with different percentage of CKD

\subsection{Effect of CKD on Unconfined Compression} Strength (UCS)

Compaction tests were also done by admixing $\mathrm{BC}$ soil and CKD by varying percentage of $4 \%, 8 \%, 12 \%, 16 \%$ and $20 \%$ to determine the dry density and optimum moisture content for each combination. Table: 4 shows summarized values of MDD and OMC obtained for BC soil and different percentage of CKD. Figure: 4 Compaction curves obtained for $\mathrm{BC}$ soil alone and $\mathrm{BC}$ soil admixed with different percentage of CKD.

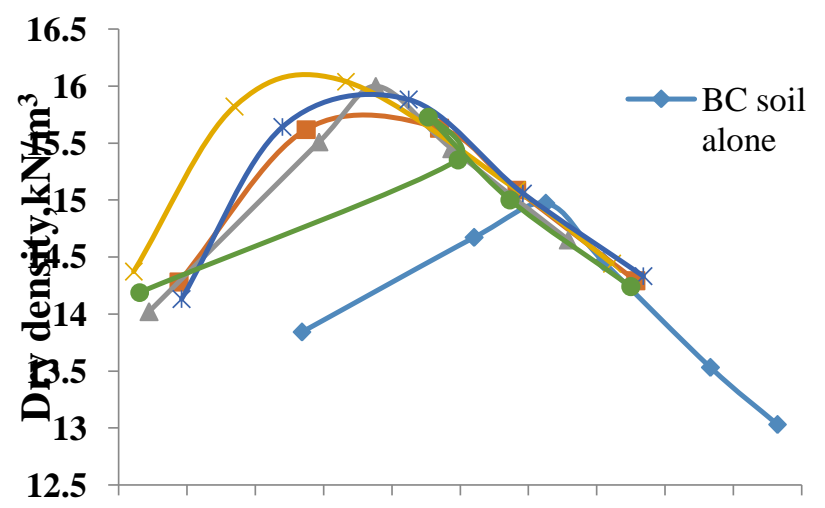

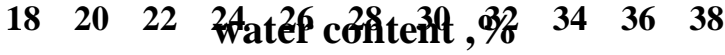

Fig 4 Compaction Curves Obtained for BC Soil Alone and BC Soil Admixed with Different Percentage of CKD

Unconfined Compression Test (UCS) moulds were prepared by mixing $\mathrm{BC}$ soil with $\mathrm{CKD}$ at $4 \%, 8 \%, 12 \%, 16 \%$ and $20 \%$. The CKD was mixed in terms of total weight of solids and samples were remoulded using water content corresponding to OMC obtained and dry density from the compaction test. The effect of curing was also verified by keeping CKD admixed BC soil in a plastic wrapper and kept in desiccators for a period of 7days, 14days and 28days.

- Soil $+0 \% \mathrm{CKD} \rightarrow\{0,7,14,28$ days curing $\}$

- Soil $+4 \% \mathrm{CKD} \rightarrow\{0,7,14,28$ days curing $\}$

- Soil $+8 \% \mathrm{CKD} \rightarrow\{0,7,14,28$ days curing $\}$

- Soil $+12 \% \mathrm{CKD} \rightarrow\{0,7,14,28$ days curing $\}$

- Soil $+16 \%$ CKD $\rightarrow\{0,7,14,28$ days curing $\}$

- Soil $+20 \% \mathrm{CKD} \rightarrow\{0,7,14,28$ days curing $\}$

Fig. 5 shows variation of UCS obtained for BC Soil+ CKD at different curing period and at different percentage of CKD

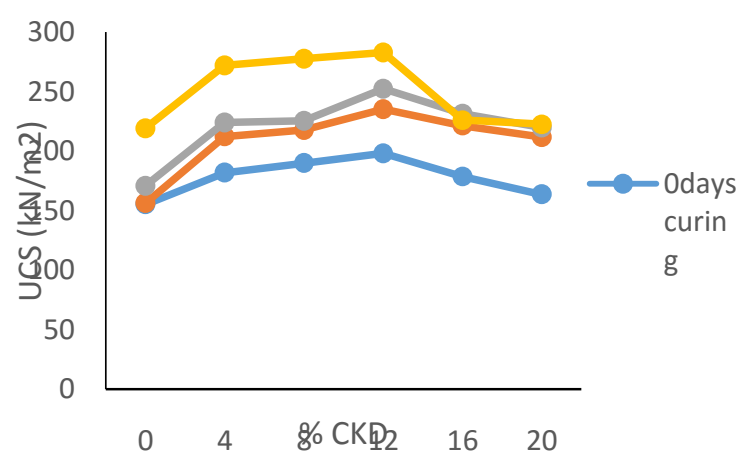

Fig 5 Variation of UCS with CKD in Percentages at Different Curing Periods 
It can be seen that, for a given percentage of CKD, increase in curing period increases UCS. Further maximum UCS value has been observed corresponding to $\mathrm{BC}$ soil admixed with $12 \%$ CKD.

\section{CONCLUSION}

On the basis of present experimental study, the following conclusions are drawn:

- Both liquid limit and plastic limit increases with increase in CKD percentage. When percentage of CKD increases beyond $12 \%$ a consequent reduction in plasticity index occurs.

- Variation of $\mathrm{pH}$ of $\mathrm{CKD}$ admixed $\mathrm{BC}$ soil indicates marginal increase in $\mathrm{pH}$ when $\mathrm{CKD}$ was between $4 \%$ to $8 \%$. There after the $\mathrm{pH}$ reduces and stabilizes beyond $12 \%$ CKD.

- $\quad$ BC soil admixed with $12 \%$ CKD showed significant increase in maximum dry density with a corresponding reduction in OMC optimum moisture content which is desirable.

- The maximum UCS value has been observed corresponding to $\mathrm{BC}$ soil admixed with $12 \% \mathrm{CKD}$. It was found that UCS increases with increase in curing period for BC soil admixed with $12 \%$ CKD. Hence it was concluded that $12 \% \mathrm{CKD}$ produce optimum benefits in terms of reduction in plasticity and increase in strength of BC soil admixed with CKD.

\section{REFERENCES}

[1] Southgate, H.E, and Mahboub, K.c. (1994), Proposed Uniform Scale For Stiffness of Unbound Pavement Materials For Pavement Design, Journal of Transportation Engineering, Volume 120, NovemberDecember.

[2] Nagih M. El-Rawi, Mohammad M.Y. and ALSAMADI(1995), Optimization of Cement-LimeChemical Additives to Stabilize Jordanian Soils, Journal Of Islamic Academy Of Sciences 8:4, 167174, 1995, College Of Engineering, University Of Baghdad, Iraq.

[3] Olaniyan, O.S., Olaoye, R.A, Okeyinka, O.M, and Olaniyan, D.B,(2011), Soil Stabilization Techniques Using Sodium Hydroxide Additives, Volume 11, No 6, Department Of Civil Engineering, Ladoke Akintola University of Technology Ogbomoso Oyo State Nigeria.

[4] F.O.P. Oriola and G. Moses(2011), Compacted Black Cotton Soil Treated with Cement Kiln Dust as Hydraulic Barrier Material, American Journal of Scientific and Industrial Research, Department of Civil Engineering, Nigerian Defense Academy, Kaduna, Nigeria.

[5] M. Heeralal, G.V. Praveen (2011), A Study On Effect Of Fibre On Cement Kiln Dust (CKD) Stabilized Soil, JERS/Vol. II/ Issue IV/October-December, 2011/173177

[6] Hossein Moayedi, Bujang B.K. Huat, Fatemeh Moayedi, Afshin Asadi, Alireza Parsaie(2011), Effect of Sodium Silicate on Unconfined Compressive
Strength of Soft Clay, volume 16. Department of Civil Engineering, Isfahan Science and Research Branch, Islamicazad University, Isfahan Iran

[7] Dhiaadin Bahaadin Noory Zangana (2012), The Effect of Sodium Hydroxide on The Strength of Kirkuk Soil - Cement Mixtures, Civil Engineering Department, College of Engineering, University of Sulaimani.

[8] Khater.H.M(2012), Effect of Cement Kiln Dust on Geopolymer Composition and Its Resistance to Sulphate Attack, Volume 2, No 3, Housing and Building National Research Centre, Cario, Egypt

[9] Iorliam, A. Yala, Agbede, I. Olufemi, Joel, Manasseh(2012), Effect of Cement Kiln Dust on Some Geotechnical Properties of Black Cotton Soil, Volume. 17, Department of Civil Engineering University of Agriculture, Makurdi, Benue State, Nigeria

[10] P. Ramesh, A. V. Narasimha Rao, N. Krishna Murthy (2012), Efficacy Of Sodium Carbonate And Calcium Carbonate In Stabilizing A Black Cotton Soil, International Journal Of Emerging Technology And Advanced Engineering, Volume 2, Issue 10,October, Dept. Of Civil Engineering, Sree Vidyanikethan Engineering College, A.P , India,

[11] Pankaj R. Modak, Prakash B. Nangare, Sanjay D. Nagrale, Ravindra D. Nalawade, Vivek S. Chavhan (2012), Stabilisation of Black Cotton Soil Using Admixtures, International Journal of Engineering and Innovative Technology (IJEIT) Volume 1, Issue 5,

[12] Y. Keerthi, P. Divya Kanthi, N. Tejaswi, K. Shyam Chamberlin, B. Satyanarayana (2013), Stabilization of Clayey Soil using Cement Kiln Waste, International Journal of Advanced Structures and Geotechnical Engineering, Vol. 02, No. 02, April, Department of Civil Engineering, K L University, Guntur, Andhra Pradesh, India

[13] Sarat Kumar Das and Partha Sarathi Parhi (2013), Stabilization of Expansive Soil Using Alkali Activated Fly Ash, Proceedings of Indian Geotechnical Conference December, Civil Engineering Department, NIT, Rourkela.

[14] Raja Rajeshwari B. Vibhuti, Dr. V. Ramesh (2014), Stabilization of Black Cotton Soil Using Lime and Rice Husk Ash, Vol 2 Issue 6 June, 2014

[15] Partha Sarathi Parhi (2014), Stabilization of Expansive Soils using Alkali Activated Fly Ash, Department of Civil Engineering, National Institute of Technology Rourkela, Odisha -769008, India. 